\title{
Is determining nasal eosinophil count and nasal eosinophil peroxidase concentration clinically useful in children with rhinits?
}

\author{
Bong Seok Choi, MD \\ Department of Pediatrics, School of Medicine, Kyungpook National University, Daegu, Korea
}

Eosinophilic inflammation of the nasal mucosa is a characteristic feature of allergic rhinitis. ${ }^{1)}$ Large quantities of eosinophils, neutrophils, mononuclear cells, and basophils migrate into the nasal mucosa during a late-phase nasal allergic reaction, which peaks 6-12 hours after a nasal allergen challenge. ${ }^{1)}$ This response is considered important for establishing disease chronicity. ${ }^{2)}$

The measurement of nasal eosinophil level was proposed as a useful strategy for evaluating eosinophilic inflammation in patients with allergic rhinitis. ${ }^{3,4)}$ However, such measurements can vary by investigator experience and skills. ${ }^{5}$

Eosinophils release oxygen radicals and proteins including eosinophil major basic protein, eosinophil cation protein (ECP), eosinophil-derived neurotoxin (EDN), and eosinophil peroxidase (EPO). These proteins are reportedly related to nasal epithelial damage, subepithelial fibrosis, and hyper-responsiveness. ${ }^{6)}$ ECP and EDN are secreted by neutrophils and eosinophils. ${ }^{7)}$ In contrast, EPO, the most abundant cationic protein in toxic granules, is a toxic protein secreted only by eosinophils and used as an eosinophil-specific marker. ${ }^{8)}$ A more important consideration than the simple presence of eosinophilia is whether eosinophils degranulate within the target tissue. Instead of measuring eosinophil counts, researchers have attempted to identify eosinophilic inflammation by measuring eosinophil-specific toxic granules released into lesions. However, the optimal method for EPO measurement is currently lacking, and little is known about the relationship between nasal EPO and eosinophilia in children. In addition, the diagnostic cutoff values of EPO level indicative of eosinophilic inflammation have yet to be established. Therefore, the study conducted by Choi et al. . $^{9}$ published in the current issue reveals the relationship between eosinophils and EPO and provides cutoff values for EPO levels that indicate eosinophilic inflammation.

This study showed a statistically significant correlation between eosinophil count and percentage. EPO values showed a stronger correlation with nasal eosinophil counts than with percentage. Two eosinophil counts on the nasal eosinophil count test showed the largest area under the curve value obtained from the receiver operating characteristic curve. The EPO cutoff value was $17.57 \mathrm{ng} / \mu \mathrm{g}$. This study also revealed that nasal eosinophil count and percentage were higher in the allergic rhinitis group. However, EPO was not significantly higher in the allergic rhinitis group than in the nonallergic rhinitis group. The authors explained that an increasing eosinophil count during allergic rhinitis is not an indication of eosinophilic inflammatory activation.

Previous studies evaluated the association between eosinophils and EPO in the sputum. ${ }^{10,11)}$ However, evaluations of this association in nasal secretions are rare, especially in children, which is the strength of this study.

This study is limited by its small number of subjects. Considerations for sensitized allergens and status of exposure to these allergens would have increased the study's strength. Further large-scale studies are needed to confirm the clinical implications and cutoff value of EPO in
Corresponding author: Bong Seok Choi, MD Department of Pediatrics, School of Medicine, Kyungpook National University, 130 Dongdeok-ro, Jung-gu, Daegu 41944, Korea

Tel: $+82-53-200-5704$

Fax: +82-53-425-6683

E-mail: bschoi@knu.ac.kr

https://orcid.org/0000-0002-2129-7232

Received: 22 May, 2019

Revised: 19 June, 2019

Accepted: 5 July, 2019

\section{Copyright (® 2019 by The Korean Pediatric Society}

This is an open-access article distributed under the terms of the Creative Commons Attribution NonCommercial License (http://creativecommons.org/ licenses/by-nc/4.0/n which permits unrestricted noncommercial use, distribution, and reproduction in any medium, provided the original work is properly cited. 
children with allergic rhinitis.

Although nasal eosinophil count measurement is not routinely recommended for patients with rhinitis, it could reflect the current status of nasal eosinophilic inflammation and can be useful for differentiating nonallergic rhinitis with eosinophilia syndrome from nonallergic rhinitis. The universal use of this test can enable us to provide optimal treatment to these patients. Introduction of the nasal EPO test into the clinical setting could help us gain information about active nasal eosinophilic inflammation.

\section{Conflicts of interest}

No potential conflict of interest relevant to this article was reported.

\section{References}

1. Adkinson Jr NF, Bochner BS, Burks AW, Busse WW, Holgate ST, Lemanske RF, et al. Middleton's allergy E-book: principles and practice. Philadelphia (PA): Elsevier Health Sciences, 2013.

2. Moqbel R, Levi-Schaffer F, Kay AB. Cytokine generation by eosino- phils. J Allergy Clin Immunol 1994;94(6 Pt 2):1183-8.

3. Ahmadiafshar A, Taghiloo D, Esmailzadeh A, Falakaflaki B. Nasal eosinophilia as a marker for allergic rhinitis: a controlled study of 50 patients. Ear Nose Throat J 2012;91:122-4.

4. Lans DM, Alfano N, Rocklin R. Nasal eosinophilia in allergic and nonallergic rhinitis: usefulness of the nasal smear in the diagnosis of allergic rhinitis. Allergy Proc 1989;10:275-80.

5. Nair P, Ochkur SI, Protheroe C, Radford K, Efthimiadis A, Lee NA, et al. Eosinophil peroxidase in sputum represents a unique biomarker of airway eosinophilia. Allergy 2013;68:1177-84.

6. Christodoulopoulos P, Cameron L, Durham S, Hamid Q. Molecular pathology of allergic disease: II: upper airway disease. J Allergy Clin Immunol 2000;105(2 Pt 1):211-23.

7. Sur S, Glitz DG, Kita H, Kujawa SM, Peterson EA, Weiler DA, et al. Localization of eosinophil-derived neurotoxin and eosinophil cationic protein in neutrophilic leukocytes. J Leukoc Biol 1998;63,715-22.

8. Acharya KR, Ackerman SJ. Eosinophil granule proteins: form and function. J Biol Chem 2014;289:17406-15.

9. Choi Y, Jeon H, Yang EA, Yoon JS, Kim HH. Nasal eosinophilia and eosinophil peroxidase in children and adolescents with rhinitis. Korean J Pediatr 2019;62:353-9.

10. Erjefält J, Greiff L, Andersson M, Ädelroth E, Jeffery P, Persson C. Degranulation patterns of eosinophil granulocytes as determinants of eosinophil driven disease. Thorax 2001;56:341-4.

11. Erpenbeck V, Hohlfeld J, Petschallies J, Eklund E, Peterson C, Fabel H, et al. Local release of eosinophil peroxidase following segmental allergen provocation in asthma. Clin Exp Allergy 2003;33:331-6. 